\title{
Erratum to: Storage System for Solar Plants
}

\author{
V. V. Kuvshinov ${ }^{a, *}$, V. P. Kolomiychenko ${ }^{c}$, E. G. Kakushina ${ }^{a}$, L. M. Abd Ali ${ }^{a, b}$, and V. V. Kuvshinova ${ }^{a}$ \\ ${ }^{a}$ Sevastopol State University, Sevastopol, 299053 Russia \\ ${ }^{b}$ University of Kufa, Najaf, 54001 Iraq \\ ${ }^{c}$ Nakhimov Naval Academy, Sevastopol, 299028 Russia \\ *e-mail:vvkuvshinov@sevsu.ru \\ Submitted November 20, 2019; accepted for publication November 20, 2019
}

DOI: $10.3103 / \mathrm{S} 0003701 \mathrm{X} 19050098$

The name of the third author should read E. G. Kakushina.

The affiliation under indication $b$ should read as follows:

${ }^{b}$ University of Kufa, Najaf, 54001 Iraq

The original article can be found online at

https://doi.org/10.3103/S0003701X19030046 